\title{
Representations of School Leadership and Management in Africa: A Postcolonial Reading
}

\author{
Pontśo Moorosi \\ University of Warwick, United Kingdom
}

\begin{tabular}{|c|c|}
\hline Abstract & Info \\
\hline $\begin{array}{l}\text { Perhaps one of the most scathing critiques on school } \\
\text { leadership and management literature in Africa is its } \\
\text { reliance on western models that do not quite fit the context, } \\
\text { hence a lack of relevance. In this article I present a } \\
\text { postcolonial reading of the representation of school } \\
\text { leadership and management literature in Africa. The } \\
\text { analysis suggests that school leadership and management }\end{array}$ & $\begin{array}{r}\text { Article History: } \\
\text { Received } \\
\text { November } 12, \\
2020 \\
\text { Accepted } \\
\text { February } 11 \\
2021\end{array}$ \\
\hline $\begin{array}{l}\text { literature in Africa is represented in deficient ways that do } \\
\text { not promote indigenous ways of developing leadership and } \\
\text { management knowledge and practice within the local } \\
\text { education contexts. It argues that knowledge that is located } \\
\text { in cultural and indigenous discourse might be more effective } \\
\text { and more sustainable. A postcolonial understanding of } \\
\text { educational leadership and management that acknowledges } \\
\text { the cultural context as presented in this article builds on } \\
\text { postcolonial scholarship, thereby addressing a gap in } \\
\text { educational leadership and management. The paper ends } \\
\text { with proposals for counter representations. }\end{array}$ & $\begin{array}{r}\text { Keywords: } \\
\text { Africa, } \\
\text { decolonisation, } \\
\text { indigenous, } \\
\text { postcolonial theory, } \\
\text { school leadership and } \\
\text { management }\end{array}$ \\
\hline
\end{tabular}

\section{Cited as:}

Moorosi, P. (2021). Representations of school leadership and management in Africa: A postcolonial reading. Research in Educational Administration \& Leadership, 6(3), 692-722. DOI: 10.30828/real/2021.3.6 


\section{Introduction}

Perhaps one of the most scathing critiques on school leadership and management in Africa thus far is its reliance on western models and a lack of theorisation (Bush \& Oduro, 2006; Eacott \& Asuga, 2014; Pansiri, 2011). Pansiri (2011) posits that education in Africa broadly reflects a colonial legacy and replication of the west through its notions of the national curriculum, language of instruction, examination systems and school calendars to name a few. This leads to a managerial view of educational leadership and management as it is centred on aspects that need to be closely managed (Lopez \& Rugano, 2018). Shizha (2013) contends that the school curriculum in modern-day Africa remains problematic because it negates the voices of African indigenous populations, as it continues to be delivered in foreign language that constrains learning experiences of African students. He states that postcolonial education continues to "mirror colonial education residues, ... which continue to imprison the actions, feelings, attitudes, beliefs and the conceptual capabilities" (p.6) of people indigenous to Africa. While the curriculum across schools and universities is said to reflect the colonial legacy hence the decolonisation call (Le Grange, 2016; Mahabeer, 2020), the language of delivery has been deemed even more controversial in postcolonial discourses as it has been identified as one of the most powerful ways in which colonisers erased cultural significance (Khalifa et al., 2019) and a way through which they maintained the legacy of colonialism (Mahabeer, 2020). Coombes and Brah (2000) have questioned the very use and effectiveness of anticolonial critique while using the "language of the oppressor" (p.10), with others (e.g Barry, 1995) arguing that the use of such a language acquiesces colonial structures. Educational leadership and management practices and policies have not been devoid of the 
colonial legacy. Eacott and Asuga (2014) critiqued that educational leadership practice in Africa is largely modelled along the western systems and thus reflects a strong legacy of colonialism. Pheko and Linchwe II (2008) argued that leadership and management practice is based on the Weberian bureaucratic model that differentiates the headteacher from teachers, placing the former at the apex of the school structure and giving him/her power and authority due to this position. The efficacy of this model in the African context has been questioned, with Pheko and Linchwe II (2008) and Pansiri (2011) arguing that replicating the west does not help improve Africa's education systems as the western models do not fit the African context. More recently, Lopez and Rugano (2018) blamed African countries' reliance on international aid, which, they argue "makes adopting policies and practices from the north convenient" (p. 2) even though they may be unsuitable. This implies that policies of education as well as models and approaches to leadership and management in schools are informed by western experiences and implemented in a context that is not suitable and, significantly, in a context where local indigenous knowledge systems have been and continue to be undermined by the colonial legacy (Khalifa et al., 2019). As Khalifa et al argue, school leadership literature in nonwestern contexts is thus missing decolonising and indigenous ways of doing leadership.

It is against this background that, in this article, I offer a postcolonial reading of school leadership and management literature in Africa; contributing to postcolonial scholarship that started around the context of education in general and school leadership and management in particular (Eacott \& Asuga, 2014; Shizha, 2013; Pansiri, 2011). The intention behind the adoption of this analysis is twofold: first, it is to reveal and problematise colonial ways in which 
school leadership and management literature as a body of knowledge has been represented; and second, to highlight some counter representations and explore possible ways of rethinking school leadership and management. There are two primary questions driving this analysis: i) how is school leadership and management in Africa represented in the literature? ii) what possible indigenous counter-representations exist and how can they be built on to ensure sustainability of effective leadership practice within the African context? In postcolonial reading, representation refers to how, from the period of empires onwards, knowledge about Africa as the 'Other' was produced and interpreted, and ultimately passed through western lenses back to the colonised themselves (Coombes \& Brah, 2000). Wolf (2000) argues that representation is riddled with power relations between the dominant (west) and the dominated (non-west).

For purposes of this analysis, the continent of Africa is used to contain and contextualise the argument, but the material used refers mostly to the region of sub-Saharan Africa, which experienced colonisation by Europe. However, even within the sub-Saharan African region, it should be noted that there are national differences hence, there is no single national culture. These sub-Saharan African countries (with the exception of Ethiopia) were colonised by different European countries and have been subjected to different colonial experiences, all of which left devastating impact of colonial education which is partly responsible for the present African underdevelopment (Mudimbe, 1988; Ocheni \& Nwankwo, 2012). In this paper, I draw from individual countries, which are used as examples to illustrate arguments, and are not to be construed as representative of the region or the continent. Although political decolonisation ended in the 1960s in this region, with most countries 
gaining their sovereignty and independence, the colonial legacy remains and has shaped the educational landscape permanently. Yet, African education systems are hardly comparable to their colonisers' systems upon which they were modelled.

After this introduction I present a brief background to the postcolonial educational leadership and management literature, followed by an overview of the postcolonial theory used as both theory and conceptual framework for this analysis. I then tackle the key focus on the representation of school leadership and management literature in Africa, articulated in three contentions that are intended to bring attention to how the colonial past has shaped and continue to shape knowledge in the field and how the postcolonial present is ignoring the 'erosion' of pre-colonial knowledge. The paper ends with some suggestions that offer a counter view of the representations of school leadership and management literature, and some implications for research.

\section{Educational Leadership and Postcoloniality}

The recent surge of the decolonisation discourse, in the wake of the \#RhodesMustFall and \#FeesMustFall campaigns in South Africa in 2016, has given a boost to the decolonisation agenda in higher education globally and including in Africa as a continent. The much more recent resurgence of the BlackLivesMatter movement, sparked by the racist killing of an unarmed black man in the United States, added an impetus to the decolonisation discourse albeit with a much stronger focus on race equality and a call to end racism particularly in the Anglophone countries. While the \#RhodesMustFall movement was initiated within African educational institutions, campaigning for the decolonisation of the western modelled curriculum in African educational institutions, the decolonisation agenda is mostly focused 
on higher education and remains visibly absent in African schools (Le Grange, 2016). This, despite countries such as South Africa having gone through a series of curriculum changes since the end of apartheid over two decades ago (Mahabeer, 2020). Noticeably, the school leadership and management literature is still silent on decolonisation, making this analysis relevant and necessary as it addresses an existing gap.

There is only a handful of studies in school leadership and management literature in Africa that take a postcolonial perspective (e.g Eacott \& Asuga, 2014; Pansiri 2011) or adopt the use of postcolonialism as a theoretical lens in exploring school leadership and management practice (Mestry \& Schmidt, 2012). Without claiming to have conducted a thorough and systematic search, some literature with postcolonial references decries the loss of indigenous knowledge and practices that were more communal, collaborative and people-centred and have been replaced by bureaucratic and hierarchical models that centre power and decision-making in central administration (Obiakor, 2004; Onukwuba, 2018; Pheko \& Linchwe II, 2008). Others have problematized the notion of Anglophone Africa funding by the north as uncritical continuance of the colonial legacy at the expense of localised and indigenous ways of knowing (Eacott \& Asuga, 2014; Lopez \& Rugano, 2018). Pansiri (2011) had earlier criticised the uncritical adoption of western models of educational leadership and management, arguing that they do not help improve performance in African schools, while Mestry and Schmidt (2012), as well as Lopez and Rugano (2018), posed a postcolonial feminist critique of women school principals and their leadership practice in South Africa and Kenya respectively. These authors argue that women's leadership in education ought to be understood within the postcolonial context that denounces universality of gendered 
experiences and acknowledges differences of culture as significant shapers of experiences. Although these scholars engage a muchneeded postcolonial discourse, they are only a handful.

As a theoretical lens, postcolonialism is yet to make its mark in educational leadership studies. Khalifa et al. (2019) confirmed that "educational leaders inherited colonial leadership structures and practices that were meant to wipe indigenous cultures, norms, languages, spiritualities, and epistemologies clean of "indigeneity"' (p. 572), and that the scholarship of educational leadership has thus far not provided enough resistance or challenge to the colonising legacy. Khalifa et al. takes a global perspective to analysing indigeneity and concluded that western colonial approaches to school leadership needed decentering, while we centre "the experiences of people with a colonial past in order for authentic meaningful change to occur" (Lopez \& Rugano, 2018: 2). For Lopez and Rugano (2018), authentic meaningful change would genuinely occur if those whose indigenous knowledge systems and histories have been eroded could become part of the reconstructed social realities. The reconstruction of social realities can be achieved through a postcolonial theoretical lens.

\section{Postcolonial Theory}

Loomba (2015) describes postcolonialism as a body of theory and a field of study that seeks to critically examine the legacy of western colonialism in non-western contexts such as Africa. In arguing for a postcolonial lens, Ahluwalia (2001) posited that colonisation of Africa eroded everything positive about Africa and represented everything about Africa as negative including socialising them to hating their history and culture. Postcolonialism has thus been regarded as a particularly useful discourse for empowering 
those who have been marginalised, helping them to make sense of and reconstruct their social realities. Ahluwalia (2001) argued that the adoption of a postcolonial perspective in understanding colonialism in Africa does not necessarily negate the relevance and significance of other theories, but that it enhances and develops the argument for postcolonial identity.

Shizha (2013) confirms that indigenous knowledge systems have been eroded and invaded by western belief systems, western epistemology and ontology that invaded African culture, influencing particular forms of representation that do not necessarily serve to benefit the continent. Nkomo (2011) observed the tension with regard to the "dominant portrayal" of 'African' leadership and management in the mainstream literature. While her review was based on general organisational management and leadership literature, it nonetheless revealed an unsettling characteristic of deficiency that is "rooted in essentialist racial and colonial stereotypes of Africa" (p.370). She observes further that, some counter narratives have been offered in response to these dominant portrayals, however, they do very little to disrupt the discourse because not only do they "evoke a unique 'African' identity that is "predicated on essentialism and a recovery of the grandeur of pre-colonial Africa reminiscent of some anticolonial discourse", they also "end up reinforcing 'African' otherness, retarding progress towards an emancipatory discourse about leadership and management in Africa" (Nkomo, 2011, p.370).

Bhabha (1994) contended that postcolonialism is not only an issue for the formerly colonised but for the colonisers as well, as both cultural identities have been affected by colonialism. Postcolonialism is therefore viewed as heterogeneous entity that must be interrogated from multiple perspectives (Chen \& Mason, 2018; Young, 2001). 
Young (2001) acknowledged the heterogeneity of colonialism should be engaged both in terms of where colonialism happened and who the colonisers were; whether in the case of a classical colonisercolonised relationship between Europe and Africa or colonised becoming the coloniser with Australia as the case in point, or decolonisation followed by recolonisation in the case of Hong Kong (Williams, 1997). These scholars argued that while the colonised battle with the on-going consequences of colonialism on the economy, culture and education, the coloniser faces the epistemological challenge of their superiority manifested in western knowledge and representation. Hence, analysis of leadership representation ought to be examined in both western and nonwestern contexts. Khalifa et al.'s (2019) review is thus appropriately placed as a post-colonial analysis of school leadership literature in both western and non-western contexts. They argue that the way in which school leadership knowledge is produced and reproduced in western contexts, bears implications for how leadership is understood and interpreted in non-western contexts.

This complex intersection of postcolonialities is a hallmark of postcolonial theory, that endorses the notion of multiple perspectives of colonialism (Chen \& Mason, 2018), and supports Williams' (1997) earlier argument that the centrality of colonialism should not only be between the centre (coloniser) and the margins (colonised) but also within the margins (among the colonised). Postcolonial heterogeneity must thus be recognised even within the same geographical location, necessitating a multiplicity of perspectives and meanings in different cultural contexts that suggest a diversity of ways in which the legacy of colonialism can be addressed and overcome. Indeed, Chen and Mason (2018) point to the cultural situatedness of leadership, which 
they argue should be taken into consideration when analysing leadership practice.

Another view of the postcolonial heterogeneity is seen in the diversity of its theoretical underpinnings, intellectual positions and practices of postcoloniality that straddle many interdisciplinary fields. Nkomo (2011) posits that postcolonial heterogeneity with its multiplicity of theoretical underpinnings raises questions for its relevance to Africa, wherein some sceptics have questioned the relevance of postcolonial theory to Africa (Ahluwalia, 2001). Indeed, in examining the complexity of postcolonialism, Williams (1997) likened postcoloniality to other "ideological tendencies and movements prefixing themselves with 'post', [that] often end up in the warehouse of unclaimed mail" (821). He saw the use of 'post' in ideologies such as "poststructuralism, postmodernism and postfeminism" as "naïve triumphalism, ... premature and even presumptuous celebration of ascendancy [that] have laid them open to harsh, retributive justice" (821). Ahluwalia (2001) has however, defended the use of postcolonialism as different from other 'postisms' in that postcolonialism takes into consideration specific historical processes and how the colonies themselves were affected. It is perhaps somewhat unsurprising that this debate happened as the silence or absence of or limited focus on the African input in the "theoretical formulations" (p. 9) of postcolonialism was observed, which would ironically imply that the legacy of colonialism was very much alive. Nonetheless, others have maintained that postcolonialism does not in any way suggest that colonialism has materially ended, with Loomba (2015) arguing that this would be premature "when the inequities of colonial rule have not been erased" (p. 28). 
It is against this theoretical landscape that the continuing absence of postcolonial theory is observed in education studies and particularly in school leadership in Africa. The extent to which the representation of school leadership literature disrupts or reinforces the dominant discourses of African otherness becomes the focus of this article.

\section{Representations of African School Leadership and Management Literature}

This section focuses on the representations of school leadership and management literature in Africa. I make three contentions as a way of situating my argument on how school leadership and management literature is represented through the postcolonial lens. These contentions are based on three themes: conceptualisations of school leadership and management, school leadership preparation and development and social justice leadership.

\section{Conceptualisation of Leadership and Management}

The first contention I make is that African school leadership and management literature is modelled on prescriptive and normative western theorisation that depicts African practice as deficient. The normativity of [western] educational leadership theories is indicated by Bush (2020a), who states that theories of educational leadership tend to be normative, hence they are more likely to "reflect beliefs about the nature of educational institutions and how people behave in those institutions, rather than reflect the analysis of actual practice. It is in this normative feature of educational leadership theory that African school leadership practice and its [in]effectiveness tends to be [mis]represented and 
[mis]construed in western terms that are accepted as the norm. In this normativity, African school leaders conceive of their role in managerial terms that are remnants of the colonial legacy informed by western bureaucratic and hierarchical norms rather than visionary strategic terms that are reminiscent of precolonial leadership discourses (Besong, 2013; Lopez \& Rugano; 2018; Zame et al., 2008).

A postcolonial reading of school leadership and management finds the very notion of hierarchical leadership in a school setting wherein a school principal at the top of organisational hierarchy, authoritative and problematic. While this notion is currently an unquestioned permanent feature of the school organisational structure, it sits in contrast with traditional African practice of education (Pheko \& Linchwe II, 2008). Pheko and Linchwe II state that the traditional Setswana, "a leader is a member of the group and she/he does not occupy a hierarchical position" (p.401). Here decisions are reached by consensus. Khalifa et al. (2019) problematize the way school leadership is conceptualised in the western colonial literature, arguing that it is narrowly (my emphasis) confined to what happens in schools, ignoring what happens in communities, particularly for non-western contexts. Indeed, Pheko and Linchwe II (2008) argued that the postcolonial model of schooling presumes that only teachers in schools are the experts - another discord against the traditional sense where the transmission of traditions, skills and knowledge was imparted by all elders around children.

The hierarchical notions of leadership depict principal leadership as the most important figure in a school who has to demonstrate knowledge on all aspects including "the curriculum, student growth and development, assessment, and best teaching practices" (Zame et al., 2008, p. 117). The challenge with this notion is 
that it is not always possible to have such knowledgeable individuals, and with this lies the inevitability of portraying school principals as inadequate. Pheko and Linchwe II (2008) argue that this lends the principals with no support from the teachers leading some schools to be an ineffective one-man show. Secondly, leaders are often found to perceive their roles in managerial rather than leadership terms (Zame, et al., 2008; Lopez \& Rugano, 2018) and this is always viewed as deficient, as it does not fit the current global leadership practice. Khalifa et al. (2019) suggest that Indigenous and postcolonial scholarship of leadership portrays leadership in Africa as a communal, decolonising practice that is less hierarchical and that offers group rather than individual decision-making.

Perhaps if one considers the notion of policy borrowing within the globalised world in which learning happens in the postcolonial era, the application of western conceptualised models to the African context is inevitable. Indeed, Elonga Mboyo argues, in this special issue, that this sharing of models across different contexts might be a helpful way forward in terms of bridging the gap between different west and non-western contexts. However, it is its uncritical application that is problematic. A postcolonial perspective negates purity of the pre-colonial state, suggesting the inevitability of a compromise.

\section{Leadership Preparation and Development}

The second contention is regarding the representations of school leadership preparation and development literature. In recognition of the difference of roles and responsibilities in teaching and leadership, school leadership preparation and development is primarily concerned with specific ways in which anticipation for leadership positions and capacity for leadership is built and 
leadership is continually developed. There are three reasons why the focus on school leadership preparation and development is relevant to postcolonial analysis. First, the conceptualisation of school leadership and management above, has a direct bearing on the construction of leadership preparation and development programmes of school leaders. The hierarchical model of school leadership foregrounds only the preparation and development of school principals or headteachers and their poor performance is usually linked to their inadequate preparation (Zame et al., 2008; Kitavi and Westhuizen, 1997). Second, it has been identified as a "hot topic" (Eacott \& Asuga, 2014) and a significant area of research in three of the most recent reviews of educational leadership research in Africa (Bush \& Glover, 2016a; 2016b; Hallinger, 2018). The third reason revolves around what Pansiri (2011) and Eacott and Asuga (2014) problematised as the colonial legacy of policy interventions for leadership development that perpetuate dependence of Africa on the west through aid agencies that exclude localised knowledge and lack contextual friendliness. This includes frameworks and policies [or lack thereof] of school leadership preparation and development programmes that are continually influenced and funded by the west and replicate western practices under the pretext of global responsiveness. School principals in many African schools are portrayed as inadequately prepared after their appointment was based on [good] teaching credentials and with no specific training for principalship (Bush 2020b; Bush \& Oduro, 2006; Kitavi \& Van der Westhuizen, 1997; Zame et al., 2008). This literature maintains that school principalship requires specific preparation because it is a different role from teaching and requires different skills. While this argument holds true, it is the same conception that renders teaching insufficient preparation for principalship. Here, teaching and leading 
are presumed to be separate functions with each having its own place and [possibly] its own actors. This separation of roles ignores the interactive nature of the learning process that is inclusive of the whole community. Indeed, Maharasoa and Maharasoa's (2004) analysis of the Basotho people supports Tedla's (1992) analysis of some Ethiopian people in terms of the traditional educational practices of the indigenous African people. In these traditional African settings both children and adults learn together where the transmission of values and preparation for adulthood occurred. "There is no distinction between formal, nonformal, or informal education ... the entire community is continually engaged in learning and teaching" (Tedla, 1992, p. 7).

The emergence of the literature on school leadership preparation and development is linked to the global shift from management to leadership which, according to Bush (2008), signalled a more meaningful change of focus on the role of school leaders as leaders of change and agents in their own right rather than mere implementers of policy. In Africa, this global shift coincided with some European aid investments in the development of school leaders in some African countries: The pilot of new programme of leadership development in South Africa which introduced a formal preparation programme for school principals on a national scale. The evaluation of the pilot recommended an "entry-level qualification for new principals" (Bush, Kiggundu \& Moorosi, 2011: 41). The Kenya Educational Staff Institute (KESI) was established in 1988 with the primary focus to offer in-service training to heads of educational institutions (Asuga, Eacott and Scevak, 2015; Otunga et al, 2008), while Botswana launched a Primary School Management Development Programme (PSMDP) in 1999, which was funded by a UK-based international agency - DFID (Pansiri and Majwabe, 2020). 


\begin{abstract}
Although the South African pilot came almost two decades behind the establishment of KESI and PSMDP, the three were heavily influenced by western conceptions of preparation for school leadership that put more emphasis on certification of school principals over localised experiential knowledge. The latter could arguably have more contextual relevance and sustainability when it is made to be more inclusive. Indeed, Lopez and Rugano (2018) make a useful observation that the emphasis on qualifications appears to outweigh skills that the principals would have acquired throughout the length of their experience as teachers. Eacott and Asuga (2014) argue that the reliance of Africa on the west legitimises views of Africa as the deficient other, while Khalifa et al. (2019) argue that it undermines knowledge as experienced and dislodges an educative process of "oral community traditions" ( $p, 585)$.
\end{abstract}

Besides a few programmes identified above, the literature on school leadership preparation and development on the African continent has been consistently critical on the absence of preparation training for school principals (Asuga, Scott and Scevak, 2015; Arikewuyo and Olalekan, 2009; Bush, 2020; Bush \& Glover, 2016b; Moorosi \& Bush, 2011) suggesting that the efficacy of school leadership cannot be established unless leaders have undergone specific preparation training programmes. This body of literature has depicted school leadership to be wanting in the majority of public schools in most African states, particularly when it comes to their lack of functionality and effectiveness in improving student performance. Pitting Africa against globally developed systems of the west and particularly those that are responsible for the state of coloniality in Africa, is a statement of othering (Barry, 1995). Moreover, the portrayal of this state of affairs not only creates challenges for newly appointed principals as studies showed (Bush, et al., 2011; Kitavi \& 
Van der Westhuizen, 1997), but continues the discourse of deficiency of leadership, as new newly appointed principals are not able to use their agency and construct leadership as they experience, but have to fit in existing discourses. Lopez and Rugano (2018) question as to how much space is left within this context for agency of school leaders, to reconceptualize and reimagine their roles. This literature is critical on the inadequacy of the systems in Africa, but it is missing the suggestions of possible and alternative indigenous ways in which localised knowledge on school leadership scholarship could be used or passed on through formal professional training and be used to "disentangle school leadership practices from this colonizing legacy" (Khalifa et al., 2019). This is important as the functionality of schools is widely linked to the efficacy of leadership, which has been shown to matter for effective school performance, particularly where student outcomes are concerned (Oduro \& Bosu, 2010; Lopez \& Rugano, 2018). The narrative and representation of underdevelopment persistently presents Africa from a deficit position. The question remains as to how Africa is to develop its own leadership and build its own capacity for leadership when mainstream paradigms of leadership are mainly based on culturally defined knowledge frameworks that are "contextually dissonant with African society" (Iwowo, 2016; p. 2). This lends itself to a more blended approach infused with aspects of western culture of formal training, but one that is more inclusive and understands leadership from an indigenous perspective.

\section{Social Justice Leadership}

The third contention concerns the representations of social justice leadership, particularly with regard to notions of equity and equality, and how they have been constructed. Social justice is central to the postcolonial discourse (Mestry \& Schmidt, 2012) and 
postcolonial feminist scholarship challenges the notion of universal gender oppression and argue for men and women to work as allies against the common oppressor that is colonialism (Parashar, 2016). It is noted that research on gender and educational leadership took a slow start in Africa, influenced by the western focus on the underrepresentation of women in leadership positions (e.g Chabaya, et al 2009; Moorosi, 2010) which was a dominant western discourse of the 90s. This preoccupation with the underrepresentation of women in leadership was premised on the assumption that as a group, women are oppressed by men, which is a white liberal feminist discourse predicated on western experiences of white women. This white feminist liberal discourse overlooked "racial, cultural and historical specificities that mark the condition" of African women (Tyagi, 2014; p.47), and failed to acknowledge the diversity of cultural contexts and the simultaneity of African men's role as oppressors of African women under patriarchy and as the oppressed themselves under colonialism. African feminist perspectives reject the western feminist dichotomization of human relations that places men against women and encourage "individualism and competitiveness" (Ngunjiri, 2010; p.757). Indeed, Arvin, Tuck and Morril (2013) confirmed that native feminism which is akin to postcolonial feminism does not view men as the sole oppressor of women. Postcolonial feminism rejects universality of gendered experiences for both men and women that ignores the uniqueness of cultural experience. In this theorisation, "Native men are not the root cause of Native women's problems; rather, Native women's critiques implicate the historical and ongoing imposition of colonial, heteropatriarchal structures onto their societies" (Arvin et al., 2013, p.18). Indeed, Freire (2000) argues that the oppressed ought to cultivate the pedagogy of their own oppression together. 


\section{Counter-Representations and Possible Ways Forward}

A postcolonial reading of the representation of school leadership and management literature reveals the literature is premised on the western notions of leadership and management that are hierarchical and bureaucratic as opposed to the community-based type of leadership that is indigenous to African communities. Said's (1978) notion that colonialism took away the ability for countries to define themselves but that the colony defined the countries in a manner that suited its terms, is depicted in what Pansiri (2011) defines as an uncritical adoption of western models of leadership and management that limit Africa's own self-determination. Khalifa et al. (2019) argued that "self-determination provides Indigenous school and community leaders with a sense of destiny and shared values that propel them to act in spite of their social and political environment" (p. 592). They add that indigenous school leaders who are aware of their communities' colonial, patriarchal, and racist history are more capable of operating within the confines of their restrictive environments, and can provide their students and school communities with a sense of purpose to challenge the status quo and usher change. A lack of congruency between colonial education and African reality created people that are abstracted from their reality (wa Thiong'o, 1986), whereby western ways of doing and knowing are seen as the norm and the usual and yet unattainable. A possible way forward would begin with Africa defining what leadership means for Africa, rather than relying on western definitions. Pheko and Linchwe II (2008) argued for the notion of school leadership that is infused with cultural practices that accommodate consultation as opposed to top-down approaches that reflect a colonial legacy. Such notions as advocated by Pheko and Linchwe II are evident in the 
collective and consensus seeking leadership models in the Setswana and Sesotho speaking culture, "kgosi ke kgosi ka batho" (in Setswana) and "Morena ke morena ka sechaba" (in Sesotho) both meaning, the Chief is a chief by the grace of the people he serves (Mokolatsie, 2020; Pheko \& Linchwe II, 2008; Prozesky, 2016).

Otunga et al. (2008) provides an account of how African children were educated before the arrival of the missionaries and their introduction of formal education. The fusion of formal, informal and non-formal education (Maharasoa \& Maharasoa, 2004; Tedla, 1992) suggests that learning and leading occur concurrently in communities with children and parents together. It is in this fusion that leadership potential emerges and gets nurtured. This speaks to notions of teacher and distributed leadership in modern western infused leadership and management. However, it is notable that in the western sense, these notions of shared leadership do not include children. Arguing that Africa goes back to its pre-colonial state would be a futile step too far. After all, as Bhabha's (1994) hybridity notion suggests, the purity of the pre-colonial state has been tainted and cannot be undone. However, there seems to be merit in arguing for indigenous ways of learning and leading that are informed by traditional notions of, for example, Ubuntu, infused with modern aspects of leading. Ncube (2010) recognised Ubuntu as a transformative leadership practice that holds promise for "progressive and ethical change for Africa" and offering an alternative to perspectives of leadership that are based purely on western perspectives. The communality interdependence of Ubuntu is thus seen as central to social justice leadership, providing solidarity and upliftment of the school community in times of need (Moorosi \& Heystek, 2021). Mangaliso (2001) argued that Ubuntu holds promise for organisational leadership and management; "organizations 
infused with humaneness, a pervasive spirit of caring and community, harmony and hospitality, respect and responsiveness will enjoy more sustainable competitive advantage" (p. 32). Indeed, Khalifa et al.'s (2019) notion of indigenous decolonising leadership speaks to notions of Ubuntu and a culturally responsive leadership. Khalifa et al. viewed culturally responsive leadership as leadership that connects leaders to students. Here, teaching, learning and leading happen concurrently. As Bhabha's (1994) notion of hybridity implies, the pure form of pre-colonial Ubuntu is unattainable. What can be achieved, through epistemological challenges, might be a more modernised version of Ubuntu that is shaped by western and nonwestern ways of knowing and leading, that would result in a cross fertilization of ideas based on cultural practices (Ncube, 2010). Elonga Mboyo (2019) advocated for a re-imagined notion of Ubuntu incorporated into school curriculum and pre-empting the pressure of the western performativity culture as the convergence between African and western cultures increase.

Postcolonialism rejects universality and sees the "universal as specific" (Nkomo, 2011; p.372). However, this universality is taken for granted when it comes to leadership theory. Although Ubuntu has been offered as an indigenous way of thinking about and practicing leadership, Nkomo (2011) cautioned against a universal treatment of Ubuntu and an essentialised acceptance of one African culture. Mbigi (2005) argued for the significance of examining the role of cultural paradigms in organisational leadership. The literature suggests different notions of Ubuntu that emphasise different aspects. Pheko and Linchwe (2008) refer to "botho" (personhood) as a characteristic of a society that expects the leader to enculturate specific approaches among people. While Mbigi's (2005) Ubuntu, emphasises communality and interdependence, botho emphasises 
virtues of good character such as hlompho (deep respect) and boikokobetso (humility), which are essential to the understanding of ethical leadership in Setswana and Sesotho speaking cultures (Mokolatsie, 2020; Pheko \& Linchwe, 2008; Prozesky, 2016) and are instilled early in life. Indeed, Prozesky's (2016) argues that consideration of such virtues have direct implications for ethical leadership in the African context. Acknowledging cultural diversity is accepting the diversity and complexity of African identities as "rooted in the post-colonial experience" (Ahluwalia, 2001, p. 9). Madimbo (2016) argued for indigenous research of leadership where it resides in its cultural and social context. This is useful as it helps provide an understanding of the strategies the leaders employ to move beyond historical barriers and into being successful leaders. Pre-colonial values and virtues are advocated here as a vision for decolonising leadership and management. These to be considered within an integrated model with aspects of modern western leadership is a useful way forward, in recognition of the hybrid state of postcoloniality. The implications for leadership development are that, in the communal sense, school leadership development focuses on building capacity for leadership and the development of individual leaders within the broader context. Eacott and Asuga (2014) called for the construction of school leadership development as an ongoing research object, rather than just the confirmation - or disconfirmation - of the researcher's model of what that reality should be. Pheko and Linchwe (2008) argued that the modern approach to school leadership used by school principals, putting them at the centre of leadership, was inadequate in Africa, hence the need to blend this modernity with traditional aspects of leading that are community focused. A traditional view of leadership that engages wider community involvement blending with aspects of 
modernity suggests the tainted hybridity of Bhabha (1994) but is perhaps a necessary cross-cultural interaction compromise.

It is the prevailing liberalist agenda that gave minimal attention to the "unjust social arrangements between men and women" (Ngunjiri, 2010; p.757) in Africa. Ngunjiri (2010) and Maharasoa and Maharasoa (2004) provide a helpful perspective of African spirituality imbued with practical wisdom arguing that it leads to a deeper engagement in social justice leadership. Chen and Mason (2018) also add that, "spirituality is considered an important facet of an Indigenous perspective of leadership; it is an approach that is central to the leaders' existence, reflecting long-standing ways of seeing the world and a way of life" (p.162). This form of indigenous leadership acknowledges that school leaders operate in ways that recognize the racist culture that surrounds them but are still capable of using practices that communities to work in more inclusive ways. Accordingly, leaders are inclined to be transformative and play an inspirational role in their schools and communities. This is in line with Obiakor's (2004) African-centered education and others who advocate drawing from indigenous knowledge systems to make sense current leadership and management challenges. In this context, men, women and children work together for the benefit of the community.

\section{Conclusion}

This analysis problematizes the representations of African school leadership and management literature. I focused the argument on three themes: conceptualisations of educational leadership and management, leadership preparation and development and social justice leadership, and contended through a postcolonial reading that 
the literature is represented as the deficient other to western norms. In addition to offering visions for decolonising educational leadership and management, this article has also served as a form of resistance expressed through a postcolonial critique and can be viewed as a significant step towards decolonisation. In the words of Freire (2000), in order to;

...surmount the situation of oppression, people must first critically recognise its causes, so that through transforming action they can create a new situation, one which makes possible the pursuit of a fuller humanity (p. 47).

Hence, I make a suggestion towards a hybrid model of educational leadership and management that incorporates indigenous African values, virtues and practices of holistic learning and leading that includes all members of the school community. I have made an attempt to integrate feminism and postcolonialism in pursuit of a postcolonial scholarship that interrogates the multiplicity of histories. In so doing, I have engaged problematically to the discourse to which I have contributed in forging space for the way forward. I acknowledge that this area needs further development and I am not claiming to "speak for the subaltern" (Spivak, 1988; p. 104) but I consider this as a form of subjective reflection in acknowledging the colonial legacy inherent in the representation of educational leadership literature in Africa. My subjective position is that of someone who has contributed to the uncritical postcolonial discourse that I now seek to critique. I reiterate making an explicit call for decolonising ways of conducting research that look deep into precolonial practices and learn localised ways of leading and managing, ways that reside within the richness and diversity of the richness of the African cultural context. This suggested research should make observe postcolonial leadership and management practices and use 
of postcolonial theories to help make sense of the African indigenous past and how it can help advance the postcolonial present to make it more effective and sustainable. As the notion of hybridity suggests, the pre-colonial cultural practice in its purity is unattainable. However, this integrated form of generating knowledge holds emancipatory chances of advancing indigeneity within African school leadership, schools and their communities.

\section{References}

Ahluwalia, P. (2001). Politics and post-colonial theory: African inflections. London and New York, NY: Routledge.

Arikewuyo, M. \& Olalekan, F. (2009). Professional training of secondary school principals in Nigeria: A neglected area in the educational system. Journal of Educational Administration and Policy, 2(2), 73-84.

Arvin, M., Tuck, E., \& Morrill, A. (2013). Decolonizing feminism: Challenging connections between settler colonialism and heteropatriarchy. Feminist Formations, 25(1), 8-34.

Asuga, G.N., Eacott, S. \& Scevak, J. (2015). School leadership preparation and development in Kenya: Evaluating performance impact and return on leadership development investment. International Journal of Educational Management, 29, 355-367.

Barry, P. (1995). Beginning theory: An introduction to literary and cultural theory. Manchester: Manchester University Press.

Besong. J.B. (2013). A comparative study of the administrative efficiency of principals in public and private secondary schools in Maroua, Far North Region, Cameroon, International Journal of Business \& Management, 8(7), 90-99.

Bhabha, H. K. (1994). The location of culture. New York, NY: Routledge. 
Bush, T. (2020a). Theories of educational leadership and management, $5^{\text {th }}$ Edition. London: Sage.

Bush, T. (2020b). How does africa compare to the rest of the world? In P. Moorosi \& T Bush (eds) Preparation and Development of School Leaders in Africa, London: Bloomsbury.

Bush, T. (2008). From Management to Leadership: Semantic or Meaningful Change: Educational Management Administration $\mathcal{E}$ Leadership, 36(2), 271-288.

Bush, T. \& Glover, D. (2016a). School leadership and management in South Africa, International Journal of Educational Management, 30(2), $211-231$.

Bush, T. \& Glover, D. (2016b). School leadership in West Africa: Findings from a systematic literature review. African Education Review, 13(3-4), 80-103.

Bush, T., Kiggundu, E. \& Moorosi, P. (2011). Preparing new principals in South Africa: the ACE: School Leadership Programme. South African Journal of Education, 31, 31-43.

Bush, T. \& Oduro, K.T. (2006). New principals in Africa: Preparation, induction and practice. Journal of Educational Administration, 44(4), 359-375.

Chen, C. \& Mason, D.S. (2018). A postcolonial reading of representations of non-western leadership in sport management studies. Journal of Sport Management, 32, 150-169

Chabaya, O., Rembe, S., \& Wadesango, N. (2009). The persistence of gender inequality in Zimbabwe: Factors that impede the advancement of women into leadership positions in primary schools. South African Journal of Education, 29(2), p. 235-251.

Coombes, A. E., \& Brah, A. (2000). Hybridity and its discontents. Politics, science and culture. London, UK: Routledge.

Eacott, S. \& Asuga, G.N. (2014). School leadership preparation and development in Africa: A critical insight. Educational Management Administration \& Leadership, 42(6), 919-934. 
Elonga Mboyo, J. P. (2019). Reimagining Ubuntu in schools: A perspective from two primary school leaders in the Democratic Republic of Congo. Educational Management Administration E Leadership, 47(2), 206-223.

Freire, P. (2000). Pedagogy of the oppressed. New York: Bloomsbury.

Hallinger, P. (2018). Surfacing a hidden literature: A systematic review of research on educational leadership and management in Africa. Educational Management Administration $\mathcal{E}$ Leadership, 46(3), 362-384.

Iwowo, V.A. (2016). In the Eye of the Beholder: Making 'sense' of Leadership Development in Africa. Academy Management Annual Meeting Proceedings 1, 1-3.

Khalifa, M. A., Khalil, D., Marson, T. E. J., \& Halloran, C. (2019). Toward an indigenous, decolonizing school leadership: A literature review. Educational Administration Quarterly, 55(4), 571-614.

Kitavi, M. W., \& Van der Westhuizen, P.C. (1997). Problems facing beginning principals in developing countries: A study of beginning principals in Kenya. International Journal of Educational Development, 17(3), 251-263.

Loomba, A. (2015). Colonialism/postcolonialism. London, UK: Routledge.

Le Grange, L. (2016). Decolonising the university curriculum. South African Journal of Higher Education, 30(2), 1-12.

Lopez, A. E., \& Rugano, P. (2018). Educational leadership in postcolonial contexts: What can we learn from the experiences of three female principals in Kenyan secondary schools? Education Sciences, 8(99), 1-15.

Mahabeer, P. (2020). Decolonising the school curriculum in South Africa: black women teachers' perspectives. Third World Thematics: A TWQ Journal, 5(1-2), 97-119. 
Maharasoa, M.M.A. \& Maharasoa, M.B. (2004). Men's initiation schools as a form of higher education within the Basotho indigenous knowledge systems, South African Journal of Higher Education, 18(3), 106-114.

Madimbo, M. (2016). Transformative and engaging leadership: Lessons from indigenous African women. London: Palgrave Macmillan

Mangaliso, M. P. (2001). Building Competitive Advantage from Ubuntu: Management Lessons from South Africa, Academy of Management Executive, 15(3), 23-32.

Mbigi, L. (2005). The spirit of African leadership. Johannesburg: Knowledge Resources.

Moorosi, P. (2010). South African female principals' career paths: understanding the gender gap in secondary school management. Educational Management Administration $\mathcal{E}$ Leadership, 38(5), 547-562.

Moorosi, P. \& Bush, T (2011) School leadership development in commonwealth countries: Learning across the boundaries. International Studies in Educational Administration, 39(3), 59-76.

Moorosi, P \& Heystek, J. (2021) Critical perspectives in educational leadership in South Africa. In S. J. Courtney, H. M. Gunter, R. Niesche, \& T. Trujillo (Eds.). Understanding Educational Leadership: Critical Perspectives and Approaches. London. Bloomsbury

Mokolatsie, C (2020). Revisiting virtue ethics and spirituality of Botho: A study of an indigenous ethic of character formation in the moral thought and practice of Basotho. (Published Ph.D Dissertation) http://hdl.handle.net/10500/26809

Mestry, R. \& Schmidt, M. (2012). A feminist postcolonial examination of female principals' experiences in South African secondary schools. Gender and Education, 24(5); 535-551.

Mudimbe, V. Y. (1988). The invention of Africa: Gnosis, philosophy and the order of knowledge. Bloomington: Indiana University Press. 
Ncube, L. B. (2010). Ubuntu: A transformative leadership philosophy, Journal of Leadership Studies, 4(3): 77-82.

Ngunjiri, F.W. (2010). Lessons in spiritual leadership from Kenyan women. Journal of Educational Administration, 48(6); 755-768.

Nkomo, E. S. (2011). A postcolonial and anti-colonial reading of 'African' leadership and management in organization studies: Tensions, contradictions and possibilities. Organization, 18(3); 365-386.

Obiakor, F. E. (2004). Building patriotic African Leadership through African-centred education. Journal of Black Studies, 34(3); 402420.

Ocheni, S. \& Nwankwo, B. C (2012). Analysis of colonialism and its impact in Africa. Cross-Cultural Communication, 8(3); 46-54.

Oduro, G. \& Bosu, R. (2010). Leadership and management of change for quality improvement. EdQual - Ghana Policy Briefs. University of Cape Coast.

Onukwuba, H. O. (2018). "Indigenous Leadership Practices in Africa", Indigenous Management Practices in Africa (Advanced Series in Management, Vol. 20), Emerald Publishing Limited, pp. 119-145.

Otunga, R., Sereme, D. \& Kindiki, J. (2008). School leadership development in Africa, in Lumby, J., Crow, G. and Pashiardis, P. (Eds.), International Handbook on the Preparation and Development of School Leaders, Abingdon: Routledge.

Pansiri, N.O. (2011). Performativity in school management and leadership in Botswana. Educational Management Administration E Leadership, 39(6); 751-766.

Pansiri, N.O. \& Majwabe, S.Z. (2020). A historical analysis of educational leadership preparation and development in Botswana. In P. Moorosi \& T. Bush (eds), Preparation and Development of School Leaders in Africa, London: Bloomsbury. 
Parashar, S. (2016) Feminism and postcolonialism: (En)gendering encounters. Postcolonial Studies, 19(4), 371-377

Pheko, B. C., \& Linchwe II, K. (2008). Leadership from two cultural perspectives - A tune or discord: Botswana's experience. International Journal of Lifelong Education, 27, 399-411.

Prozesky, M. (2016). Ethical leadership resources in southern Africa's Sesotho-speaking culture and in King Moshoeshoe I, Journal of Global Ethics, 12(1): 6-16.

Said, E. W. (1978). Orientalism New York, NY: Vintage.

Shizha, E. (2013). Reclaiming our indigenous voices: The problem with postcolonial Sub-Saharan African school curriculum. Journal of Indigenous Social Development, 2(1), 1-18.

Spivak, G. C. (1988). 'Can the Subaltern Speak?'. In C. Nelson and L. Grossberg (eds) Marxism and the Interpretation of Culture, London: Macmillan, pp. 271-313.

Tedla, E. (1992). Indigenous African education as a means for Understanding the Fullness of Life: Amara Traditional Education, Journal of Black Studies, 23(1); 7-26.

Tyagi, R. (2014). Understanding postcolonial feminism in relation with postcolonial and feminist theories. International Journal of Language and Linguistics, 1(2); 45-50.

wa Thiong'o, N. (1986). Decolonizing the mind: The politics of language in African literature. Portsmouth, UK: Heinemann.

Williams, A. (1997). The postcolonial flaneur and other fellowtravellers: Conceits for a narrative of redemption. Third World Quarterly 18(5): 821-41.

Wolf, M. (2000). The third space in postcolonial representation'. In S Simon and P. St Pierre (eds), Changing the Terms: Translating in the Postcolonial Era. Ottawa: University of Ottawa Press, 12745. 
Young, R.J. (2001). Postcolonialism: An historical introduction. Malden, MA: Blackwell Publishers.

Zame, M.Y., Hope, W.C. \& Repress, T. (2008). Educational reform in Ghana: The leadership challenge. Journal of Educational Management, 22(2); 115-128.

\section{About the author:}

Dr. Pontso Moorosi is associate professor of Educational Leadership and Management at the Department of Education Studies, University of Warwick, UK. She is also a research associate at the University of Johannesburg, South Africa, and a rated researcher by the National Research Foundation of South Africa. Her research interests include; gender in educational leadership, with specific use of feminist and intersectionality theories. She is also interested in issues concerning educational leadership preparation and development and leader identity development and researches African and UK contexts. Pontso is a member of BELMAS Council and co-convenes the gender and leadership research interest group.

Email: p.c.moorosi@warwick.ac.uk 